\title{
Evaluation of Chemical Composition of Fungal Treated and Ensiled Apple Pomace Paddy Straw in Sheep
}

\author{
Irfan Ahmad Daraz ${ }^{1 *}$, H.A. Ahmed ${ }^{1}$, A.M. Ganai ${ }^{1}$, Shaheen Kousar Jan ${ }^{2}$, \\ M.A. Bhat ${ }^{1}$ and P.A. Reshi ${ }^{1}$ \\ ${ }^{I}$ Division of Animal Nutrition, FVSc \& AH, Shuhama, SKUAST-Kashmir, India \\ ${ }^{2}$ Mushroom Laboratory \& Teaching Centre, SKUAST-K, Shalimar, India \\ *Corresponding author
}

\section{A B S T R A C T}

\section{Keywords}

Apple Pomace,

Fungal treated

straw,Chemical

composition.

Article Info

Accepted:

08 June 2018

Available Online:

10 July 2018
A study was undertaken in two phases to evaluate the effects of feeding fungal treated and ensiled apple pomace paddy straw based complete diet in the ration of eighteen female Corriedale sheep divided into three equal groups as per CRD. In phase-I, screening of two fungal strains namely Trichoderma viridae and Pleorotus florida, on the basis of their effects on chemical composition of paddy straw when grown for 14, 21 and 28 days respectively, was undertaken to select the best suited fungi for treatment of paddy straw to be used in experimental trial on sheep. Simultaneously, paddy straw was ensiled with apple pomace in different proportions to select the best silage in terms of chemical composition, to be used for feeding of the experimental animals. In this phase, chemical analysis of all the feed ingredients and experimental feeds was also carried out. Three complete rations were formulated to meet the nutrient requirements of experimental animals. In control group $\left(\mathrm{T}_{1}\right)$, roughage portion included untreated paddy straw, while in the treatment group $\mathrm{T}_{2}$, roughage portion was replaced with Trichoderma viridae treated paddy straw. In $\mathrm{T}_{3}$, roughage portion was replaced with apple pomace ensiled paddy straw. In phase-II, a 90 day growth trial was conducted with a 7 day metabolism trial at the end.

\section{Introduction}

At present, the increasing gap between demand and supply of feed/fodder for livestock not only requires higher quantity and quality of feed resources, but there is greater need for efficient management of livestock feeds and its utilization in the animal system. Many contributing factors like urbanization, increase in human and animal population particularly increase in bovine population and degradation of pasture land, which remained static in the country for last four decades have added to the shortage scenario. Furthermore, there is also direct competition for cereal grains between humans and animals viz-a-viz, the export of oil seeds and diversion of oil seeds and their by-products for industrial use leaves less feeds available for animal feeding (Ganai et al., 2014). According to an estimate by Kiran et al. 2012, there is shortage of 25 million tonnes of concentrate, 159 million tonnes of green fodder and 117 million tonnes of crop residues in India that constitutes 32, 20 
and $25 \%$ deficiency respectively. In the state of $\mathrm{J} \& \mathrm{~K}$, the situation is little worse due to large bovine population as the human to animal ratio in the state is above the national average of 1:0.4. According to Wani et al. (2014), the requirement of green fodder in $\mathrm{J} \& \mathrm{~K}$ is around 12563 thousand tonnes for 10938 thousands livestock against the availability of 7459 thousand metric tonnes. Severity of deficiency is more pronounced in Ladakh (85\%) followed by Kashmir (45\%) and Jammu (33\%) divisions. The authors reported that green and dry fodder availability is only 1.62 and $0.66 \mathrm{~kg} / \mathrm{animal} /$ day respectively constituting $2.28 \mathrm{~kg} / \mathrm{animal} /$ day which is very low as compared to the national average of $5.15 \mathrm{~kg} /$ animal/day. These factors compel animal nutritionists to look for new feed resources or improvement in the nutritive value of existing feed resources especially agricultural crop residues that can fulfill the deficiency to some extent on one hand and better use of available feed resources on the other hand. For efficient utilization of poor quality roughages, various processing methods are in vogue such as physical, chemical, biological treatment and supplementation of feed additives. Despite improvements of crop residues, the efficient utilization to desirable extent is still awaited. The key to improve the use of crop residues for ruminants is to overcome their inherent barriers in rumen microbial fermentation.

For efficient utilization of poor quality roughages, various processing methods have been used such as physical, chemical, biological treatment and supplementation with other feed ingredients or a combination of these treatments, yet improvements of crop residues to desirable extent are still awaited. Use of biological agents (lignolytic fungi) to maximize advantage from given feeds in animal system. Biological treatment of fortification of poor quality roughages is a favorable option and is believed to be more environmental friendly and safer with very low operating cost than the use of chemicals and physical treatment methods.

Agro-industrial by-products available locally are not fully exploited. Several factors have led to increased interest in utilizing such byproducts as animal feed, such as pollution abatement regulations, increasing costs of waste disposal and changes in perception of the value of by-product feedstuffs as economical feed alternatives (Khatooni et al., 2014).Such feedstuffs include by-products such as apple pomace, tomato pomace, grape pomace, sugar beet pulp and pomegranate pulp. The growth of horticulture industry in Jammu and Kashmir generates huge quantities of apple wastes as J\&K accounts $67 \%$ of total apple production in the country (Malik, 2013) with an average annual apple production of nearly 1.3482 million metric (NHB, 2013). In Jammu and Kashmir, it is estimated that 20\% of the fruit gets damaged due to various factors and are used for juice extraction and the left over is a by-product as 1.02 lakh tons of apple pomace is produced every year (NHB, 2013). Due to the presence of high amounts of fermentable carbohydrates in apple pomace, it can be potentially used as a source of soluble sugars for ensiling of poor quality roughages such as paddy straw to improve its nutritive value. So the present investigation was carried out to find out the effects of bio-fortification of paddy straw with lignolytic fungi and ensiling of paddy straw with apple pomace on nutrient utilization and growth performance of sheep.

\section{Materials and Methods}

The present study was carried out at Division of Animal Nutrition, Faculty of Veterinary Sciences and Animal Husbandry, Shuhama and Mushroom laboratory, Division of Plant Pathology, SKUAST of Kashmir, to assess the effect of feeding fungal treated and ensiled paddy straw with apple pomace based complete diet on growth performance, nutrient 
utilization of sheep. The study was carried out in two phases as under;

\section{Phase-I:}

a) In-vitro screening of different fungal strains and silages to determine the best strain of fungi and silage to be used for treatment of paddy straw under local conditions.

b) To determine the optimum ratio of combination of apple pomace with paddy straw to be used for in-vivo feeding experiment.

\section{Phase-II}

In-vivo feeding experiment of 90 days, using fungal treated paddy straw and ensiled paddy straw with apple pomace based complete diet in sheep was conducted.

\section{Data processing and analysis}

The data obtained in the experiment were analyzed using statistical procedures given by Snedecor and Cochran (1994). Significance of mean difference was tested by Duncan's New Multiple Range Test (DNMRT) using the Statistical Package for the Social Sciences (SPSS), Base 20.0, SPSS Software products, Marketing Department, SPSS Inc. Chicago, USA.

\section{Results and Discussion}

The scarcity of feeds and fodders, escalating demand and cost of concentrate feed ingredients, necessitates the role of animal nutritionists and livestock entrepreneurs to look for alternative/non-conventional feed resources (NCFR) that can fulfill the deficiency to some extent to maintain optimum productivity potential in animals on economical basis. The present scenario also necessitates the need for looking out for various technologies that can improve the nutritive value of poor quality roughages which are available in appreciable amounts but cannot be fed as maintenance diet for any species of the ruminants due to poor nutrient and high lignin content. The ligno-lytic fungi such as white rot fungi, brown rot fungi and soft rot fungi are easily available round the year and can efficiently be grown on roughages with minimum amount of look after and care. The fungus treated straws like paddy straw and wheat straw are nutritious and more palatable as compared to their untreated counter-parts. Furthermore, biological treatment of straws is an environment friendly technique that poses no threat to the environment and has no toxicity issues for the animals (Table 1-5).

\section{In-vitro treatment of paddy straw with fungi}

In this phase of the experiment, two fungal strains namely Pleorotus florida (white-rot fungus) and Trichoderma viridae (bioweedicide) were inoculated on paddy straw for 14, 21 and 28 days to assess the effect of fungal growth on improvement in the chemical composition of the paddy straw. After thorough evaluation Trichoderma viridae was selected for the treatment of paddy straw (incubated for 28 days) for growth trial in sheep owing to the hardy nature of this fungus and its capability to grow under extremes of temperature and resistance to growth of other pathogenic fungi and bacteria as well.

\section{In-vitro ensiling of paddy straw with apple pomace}

Another in-vitro experiment was conducted where paddy straw was mixed with apple pomace in the ratio of 1:3 and ensiled in air tight containers for 35 days as per method described by Anonymous, 2006; RCM report submitted to Directorate of research SKUAST-K, Shalimar by Division of Animal 
Nutrition, April 17,18, pp 7-12. After the consistency, fungal growth, odour and $\mathrm{pH}$ ensiling period was over, the ensiled mass was (Table 3) for evaluation of quality of the tested for its proximate constituents (Table 2) as well as physical attributes like color, mixture.

Table.1 Chemical composition of untreated and fungal treated paddy straw at different intervals of incubation

\begin{tabular}{|l|c|c|c|c|c|c|c|}
\hline \multicolumn{1}{|c|}{ Parameters } & $\begin{array}{c}\text { Untreated } \\
\text { paddy straw } \\
\text { (Moist) }\end{array}$ & \multicolumn{3}{|c|}{$\begin{array}{c}\text { Trichoderma viridae } \\
\text { treated paddy straw }\end{array}$} & \multicolumn{3}{c|}{$\begin{array}{c}\text { Pleorotus florida treated } \\
\text { paddy straw }\end{array}$} \\
\cline { 3 - 8 } & & $\mathbf{3 4}$ & $\mathbf{2 1}$ & $\mathbf{2 8}$ & $\mathbf{1 4}$ & $\mathbf{2 1}$ & $\mathbf{2 8}$ \\
\hline DMs & 21.03 & 20.23 & 19.42 & 17.56 & 19.13 & 17.42 & 16.50 \\
\hline DM (after sun drying) & ----- & 91.33 & 90.47 & 90.00 & 90.11 & 89.77 & 87.13 \\
\hline CP & 3.29 & 2.89 & 4.66 & 7.21 & 3.33 & $5.44 s$ & 8.22 \\
\hline EE & 1.68 & 1.91 & 2.40 & 2.80 & 1.70 & 1.91 & 2.28 \\
\hline CF & 30.39 & 28.63 & 25.42 & 21.03 & 25.86 & 19.82 & 17.47 \\
\hline NDF & 64.33 & 64.03 & 62.01 & 61.02 & 62.73 & 61.20 & 60.06 \\
\hline ADF & 47.5 & 47.20 & 45.30 & 45.06 & 46.33 & 45.02 & 44.21 \\
\hline Hemicellulose & 16.83 & 16.83 & 16.71 & 15.96 & 16.40 & 16.18 & 15.85 \\
\hline Cellulose & 35.02 & 35.42 & 32.40 & 28.22 & 31.50 & 30.66 & 29.87 \\
\hline Total Ash & 8.41 & 6.56 & 8.42 & 10.01 & 9.01 & 11.12 & 12.09 \\
\hline Lignin & 8.15 & 8.05 & 7.09 & 5.83 & 8.01 & 6.90 & 6.55 \\
\hline Ca & 0.91 & 2.02 & 2.33 & 2.77 & 2.71 & 4.74 & 5.31 \\
\hline P & 0.39 & 0.13 & 0.11 & 0.14 & 0.33 & 0.13 & 0.15 \\
\hline
\end{tabular}

Table.2 Chemical composition of apple pomace, paddy straw and silage offered to animals during growth trial

\begin{tabular}{|l|c|c|c|}
\hline Parameters & Apple pomace & $\begin{array}{c}\text { Untreated paddy } \\
\text { straw }\end{array}$ & $\begin{array}{c}\text { Ensiled paddy straw (paddy } \\
\text { straw: apple pomace, 1:3) }\end{array}$ \\
\hline DM & 15.46 & 88.91 & 70.07 \\
\hline OM & 95.11 & 90.12 & 91.36 \\
\hline CP & 4.23 & 2.69 & 3.07 \\
\hline CF $F E$ & 17.64 & 30.39 & 27.12 \\
\hline EE & 4.50 & 1.68 & 2.38 \\
\hline TA & 4.90 & 8.41 & 7.53 \\
\hline NFE & 73.63 & 44.74 & 51.96 \\
\hline NDF & 42.10 & 64.33 & 57.87 \\
\hline ADF & 21.90 & 47.50 & 40.64 \\
\hline Hemicellulose & 21.83 & 16.98 & 15.78 \\
\hline Cellulose & 37.20 & 35.02 & 35.44 \\
\hline Ca & 0.25 & 0.91 & 0.98 \\
\hline P & 0.22 & 0.39 & 0.28 \\
\hline
\end{tabular}


Table.3 Physical attributes of ensiled paddy straw with apple pomace

\begin{tabular}{|c|c|c|}
\hline S.No & Attributes & Findings \\
\hline $\mathbf{1 .}$ & Colour & Brownish yellow \\
\hline $\mathbf{2 .}$ & $\mathrm{pH}$ & 4.5 \\
\hline $\mathbf{3 .}$ & Consistency & Smooth \\
\hline $\mathbf{4 .}$ & Odour & Strongly Fruitish \\
\hline $\mathbf{5 .}$ & Fungal Growth & None \\
\hline
\end{tabular}

Table.4 Chemical composition of concentrate mixture and feed ingredients used for preparation of concentrate mixture

\begin{tabular}{|c|c|c|c|c|c|c|c|c|}
\hline \multirow[t]{2}{*}{ Parameters } & \multicolumn{7}{|c|}{ Feed Ingredients } & \multirow{2}{*}{$\begin{array}{l}\text { Conc. } \\
\text { Mixture }\end{array}$} \\
\hline & M.O.C & Maize & $\begin{array}{l}\text { Rice } \\
\text { Bran }\end{array}$ & Soyabean & Wheat Bran & Min.Mix & Salt & \\
\hline DM & 91.4 & 89.96 & 88.93 & 90.2 & 87.43 & 97.05 & 96.80 & 92.00 \\
\hline OM & 93.19 & 96.57 & 89.06 & 95.12 & 96.07 & --- & --- & 94.83 \\
\hline $\mathbf{C P}$ & 26.83 & 9.08 & 11.08 & 42.58 & 14.00 & --- & --- & 19.55 \\
\hline EE & 8.31 & 4.47 & 4.50 & 13.18 & 3.03 & --- & --- & 3.70 \\
\hline CF & 6.52 & 6.78 & 8.60 & 7.37 & 4.43 & --- & --- & 5.78 \\
\hline NFE & 51.53 & 74.24 & 64.87 & 31.98 & 74.61 & --- & --- & 68.43 \\
\hline TA & 6.80 & 3.43 & 10.94 & 4.88 & 3.92 & 100.00 & 100.00 & 7.22 \\
\hline NDF & 64.35 & 32.73 & 52.67 & 32.53 & 36.73 & --- & --- & 45.33 \\
\hline ADF & 44.11 & 21.4 & 23.14 & 25.15 & 23.18 & --- & --- & 27.77 \\
\hline Hemicellulose & 20.24 & 11.33 & 29.52 & 7.38 & 13.56 & --- & --- & 17.56 \\
\hline Cellulose & 10.60 & 10.90 & 4.90 & 13.03 & 9.03 & --- & --- & 8.83 \\
\hline $\mathbf{C a}$ & 0.10 & 0.16 & 0.32 & 0.25 & 0.26 & 29.60 & --- & 1.34 \\
\hline $\mathbf{P}$ & 0.12 & 0.39 & 1.20 & 0.78 & 0.88 & 10.20 & --- & 0.76 \\
\hline
\end{tabular}

Note: Mineral mixture consisted of Vitamin A-7,00,000 I.U, Vitamin $\mathrm{D}_{3^{-}}$70,000 I.U, Vitamin E- 250mg, Nicotinamide-1000mg, Co- 200mg, Cu- 2000mg, I- 325mg, Fe - 1500mg, Mg - 6000mg, Mn - 1500mg, K - 100mg, $\mathrm{Na}-5.9 \mathrm{mg}, \mathrm{S}-0.72 \%, \mathrm{Zn}-15 \mathrm{gm}, \mathrm{Ca}-25 \%$ and $\mathrm{P}-12.75 \%$. 
Table.5 Chemical composition of TMR offered to animals during growth experiment

\begin{tabular}{|l|c|c|c|}
\hline \multicolumn{1}{|c|}{ Parameters } & TMR1 & TMR2 & TMR3 \\
\hline DM & 90.74 & 51.50 & 90.80 \\
\hline OM & 90.47 & 90.29 & 90.20 \\
\hline CP & 10.50 & 11.13 & 12.90 \\
\hline CF & 20.30 & 17.20 & 14.90 \\
\hline EE & 2.55 & 3.96 & 3.50 \\
\hline TA & 9.53 & 9.71 & 9.80 \\
\hline NFE & 54.04 & 55.98 & 54.16 \\
\hline NDF & 53.09 & 52.60 & 48.30 \\
\hline ADF & 35.8 & 40.30 & 34.67 \\
\hline Hemicellulose & 35.87 & 40.30 & 34.68 \\
\hline Cellulose & 30.71 & 37.10 & 32.33 \\
\hline Ca & 0.80 & 1.4 & 1.90 \\
\hline P & 0.51 & 0.39 & 0.70 \\
\hline
\end{tabular}

Laboratory analysis of feed ingredients and complete rations

The chemical composition of any feed is considered as the preliminary index for the assessment of its quality. The chemical composition of untreated paddy straw (after water soaking) and fungal treated paddy straw (Trichoderma viridae and Pleorotus florida) is presented in Table 1. The chemical composition of paddy straw (water soaked) in terms of DM, CP, EE, CF, NFE, TA, AIA, $\mathrm{NDF}, \mathrm{ADF}, \mathrm{HCL}, \mathrm{CL}$, lignin, $\mathrm{Ca}$ and $\mathrm{P}$ were $21.03,3.29,1.68,30.39,56.23,8.41,2.5$, $64.33,47.50,16.83,35.02,8.15,0.91$ and 0.39 respectively.

The chemical composition of apple pomace, untreated paddy straw and ensiled paddy straw is given in Table 2. The chemical composition of apple pomace in terms of DM, $\mathrm{CP}, \mathrm{EE}, \mathrm{CF}, \mathrm{NFE}, \mathrm{TA}, \mathrm{AIA}, \mathrm{NDF}, \mathrm{ADF}$, HCL, CL, lignin, $\mathrm{Ca}$ and $\mathrm{P}$ were 15.46, 4.23, 4.50, 17.64, 73.63, 4.90, 42.10, 21.90, 21.983, $37.20, \quad 0.25$ and 0.22 respectively. The chemical composition of fungal treated paddy straw (water soaked) in terms of DM, CP, EE, $\mathrm{CF}, \mathrm{TA}, \mathrm{NDF}, \mathrm{ADF}, \mathrm{HCL}, \mathrm{CL}$, lignin, $\mathrm{Ca}$ and
P were 17.56, 7.21, 2.80, 21.03, 10.01, 61.02, 45.06, 15.96, 28.22, 5.83, 2.77 and 0.14 respectively. The chemical composition of apple pomace treated paddy straw in terms of DM, CP, EE, CF, NFE, TA, NDF, ADF, HCL, CL, lignin, $\mathrm{Ca}$ and $\mathrm{P}$ were $70.07,3.07$, 2.38, 27.12, 51.96, 7.53, 57.87, 40.64, 15.78, $35.44,0.98$ and 0.28 respectively.

\section{Phase II: In-vivo animal feeding experiment}

The in-vivo studies give complete information about palatability of feed and actual digestibility of nutrients. Hence, a feeding trial of 90 days with a metabolism trial of 7 days was conducted in the last week of the experiment.18 female Corriedale sheep were divided into three equal groups as per completely randomized design (CRD) to study the effect of feeding ensiled paddy straw (with apple pomace) and Trichoderma viridae treated paddy straw based complete diet in the different treatment groups of animals. The experimental treatment groups were designated as $\mathrm{T}_{1}$ (control), where untreated paddy straw based complete diet was fed to the experimental animals, $\mathrm{T}_{2}$,where 
ensiled paddy straw with apple pomace based complete diet was fed to the experimental animals and $T_{3}$,where fungus treated paddy straw based complete diet was fed to the experimental animals to ascertain the effect offeeding on feed intake, growth performance, physiological health status and rumen functioning of Corriedale sheep, respectively.

\section{References}

Abdel-Azim, S.N., Ahmed, M.A., Donia, F.A. and Soliman, H. 2011. Evaluation of fungal treatment of some agricultural residues. Egyptian Journal of Sheep and Goat Science 62.

Abdollahzadeh, F., Pirmohammadi, R., Farhoomand, P., Fatehi, F. and Pazhoh, F.F. 2010. The effect of ensiled mixed tomato and apple pomace on Holstein dairy cow. Italian Journal of Animal Science 9: 212-216.

Abo Donia, F.M., Abdel-Azim, S.N., Elghandour, M.M., Salem, A.z., Buendia, G. and Soliman, N. 2014. Feed intake, nutrient digestibility and ruminal fermentation activities in sheep fed peanut hulls treated with Trichoderma viridae or urea. Tropical Animal Health Programme46(1):221-228.

Aghsaghali, A.M. and Sis, N.M. 2008. Nutritive value of some agro-industrial by-products for ruminants-a review. World Journal of Zoology3: 40-46.

Ahn, J.H., Jo, I.H. and Lee, J.S. 2002. The use of apple pomace in rice straw based diets of Korean native goats Capra hircus. AsianAustralasian Journal of Animal Science 15: 1599-1605.

Anonymous, 2006; RCM report submitted to Directorate of research SKUAST-K, Shalimar by Division of Animal Nutrition, April 17,18, pp 7-12.

AOAC 2000. Official Methods of Analysis.18th edition. Association of Official Analytical
Chemists. Suitre 500, 481 North Frederick Avenue, Gaithersburg, Meryland-20877-2417, USA.

Beigh, Y. A., Ganai, A.M and Ahmad, H. A. 2015. Utilization of apple pomace as livestock feed: a review. Indian Journal of Small Ruminants, 21(2): 165-179.

Fazaeli, H., Azizi, A. and Amile, M. 2006. Nutritive value index of treated wheat straw with Pleurotus fungi fed to sheep. Pakistan Journal of Biological Sciences.9(13):2444-2449.

Fazaeli, H., Azizi, A., Jelan, Z.A., Liang, J.B. and Mirhadi, S.A. 2003. Effect of fungal treatment on the chemical composition, in-vitro digestibility and in-sacco degradability of wheat straw. Proceedings of the British Society of Animal Science 166.

Ganai, A.M., Beigh, Y. A., Ahmad, H.A. and Sheikh, G.G. 2014. Nutritional interventions for enhancing small ruminant production. Division Animal Nutrition, Faculty of Veterinary Sciences and Animal Husbandry, Sher-eKashmir University of Agricultural Sciences and Technology of Kashmir, Shuhama, Alusteng, Srinagar 190 006. August 25-29 J\&K. pp. 1-9.

Kiran, G.R., Suresh, K.P., Sampath, K.T., Giridhar, K. and Anandan, S. 2012. Modeling and forecasting livestock and fish feed resources, Requirements and Availability in India. National Institute of Animal Nutrition and Physiology, Bengaluru.

Talapatra, S. K., Ray, S. C and Sen, K. C. 1948. The analysis of mineral contents in biological materials. Estimation of phosphorus, calcium, magnesium, sodium and potassium in food stuffs. Indian Journal of Veterinary Sciences and Animal Husbandry 10:243-258

Wani, M., Zahid A.M. and Nazir, S. 2014. Spatial variability of DTPA Extractable Cationic Micronutrients in Northern part of lesser Himalayas using GIS Approach, 115th Esri India User Conference. Geo-enabling Digital India.1-14.

\section{How to cite this article:}

Irfan Ahmad Daraz, H.A. Ahmed, A.M. Ganai, Shaheen Kousar Jan, M.A. Bhat and Reshi, P.A. 2018. Evaluation of Chemical Composition of Fungal Treated and Ensiled Apple Pomace Paddy straw in Sheep. Int.J.Curr.Microbiol.App.Sci. 7(07): 1019-1025.

doi: https://doi.org/10.20546/ijcmas.2018.707.123 